Article

\title{
The Association between Blood B-Hydroxybutyric Acid Concentration in the Second Week of Lactation and Reproduction Performance of Lithuanian Black and White Cows
}

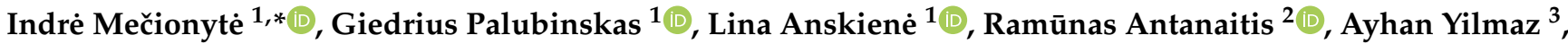 \\ Ilma Tapio ${ }^{4}\left(\mathbb{D}\right.$ and Vytuolis Žilaitis ${ }^{2}$ (D)
}

check for

updates

Citation: Mečionytė, I.; Palubinskas,

G.; Anskienè, L.; Antanaitis, R.;

Yilmaz, A.; Tapio, I.; Žilaitis, V. The Association between Blood

B-Hydroxybutyric Acid Concentration in the Second Week of Lactation and

Reproduction Performance of

Lithuanian Black and White Cows.

Animals 2022, 12, 481. https://

doi.org/10.3390/ani12040481

Academic Editor: Donald C. Beitz

Received: 21 December 2021

Accepted: 11 February 2022

Published: 15 February 2022

Publisher's Note: MDPI stays neutral with regard to jurisdictional claims in published maps and institutional affiliations.

Copyright: (C) 2022 by the authors. Licensee MDPI, Basel, Switzerland. This article is an open access article distributed under the terms and conditions of the Creative Commons Attribution (CC BY) license (https:// creativecommons.org/licenses/by/ $4.0 /)$.
1 Department of Animal Breeding, Veterinary Academy, Lithuanian University of Health Sciences, Tilžès Str. 18, 47181 Kaunas, Lithuania; giedrius.palubinskas@lsmuni.lt (G.P.); lina.anskiene@lsmuni.lt (L.A.)

2 Large Animals Clinic, Veterinary Academy, Lithuanian University of Health Sciences, Tilžès Str. 18, 47181 Kaunas, Lithuania; ramunas.antanaitis@lsmuni.lt (R.A.); vytuolis.zilaitis@lsmuni.lt (V.Ž.)

3 Department of Animal Science, Agriculture Faculty, Siirt University, 56100 Siirt, Turkey; ayilmaz@siirt.edu.tr

4 Genomics and Breeding, Production Systems, Natural Resources Institute Finland (Luke), Myllytie 1, 31600 Jokioinen, Finland; ilma.tapio@luke.fi

* Correspondence: indre.mecionyte@lsmu.lt; Tel.: +370-67-157-553

Simple Summary: Determination of BHB concentration in the second week of lactation (WK 2) may allow us to predict the fertility properties of cows and help better manage farms. BHB concentration can be considered as a predictor trait of reproduction success. High BHB concentration requires a higher amount of insemination. The season in which the cows calve and the parity must be considered in the assessment as these factors affect BHB concentration in WK 2.

Abstract: Hyperketonemia is a very common metabolic state in dairy cows, which result in lower milk production, impaired fertility, and increased frequency of other diseases. In this study, we aimed to determine the influence of season, parity, and milk yield of cows on beta-hydroxybutyrate (BHB) concentration in the second week of lactation (WK 2) and establish the relationship between BHB concentration in WK 2 and reproduction performance traits such as insemination rate and first insemination day of Lithuanian Black and White dairy cows. The study included clinically healthy Lithuanian Black and White cows $(n=692)$. Blood BHB concentration was measured using capillary blood samples collected after morning milking when cows were 7-10 DIM. The impact of WK 2 blood $\mathrm{BHB}$ concentration on the insemination rate and first insemination day were investigated. The effect of BHB was evaluated according to the season, parity, and milk yield per lactation (305 DIM). Significant differences were observed in BHB concentration in WK 2 due to season and parity, but no statistically significant differences were observed for milk yields (305 d). Increased blood BHB concentration in WK 2 negatively affected insemination rate $(p<0.001)$ and first insemination day $(p<0.001)$. The study findings indicate that BHB concentration in WK 2 depends on season and parity, while the milk yield is not associated with BHB concentration. High BHB concentration in WK 2 increases insemination rate and delays the first insemination day for high milk-yielding Lithuanian Black and White dairy cows.

Keywords: BHB; lactation; season; milk yield; fertility

\section{Introduction}

Metabolic load in high milk-yielding cows is a vital issue, and periodic changes are susceptible to a variety of metabolic and infectious diseases during transition processes (the period between three weeks before and three weeks after parturition) [1-3]. Massive mobilization of nonesterified fatty acids before, during, and after calving is a common 
metabolic feature in high-producing dairy cattle and is also an adaptive process for this new metabolic status. B-hydroxybutyrate (BHB) is the ketone body that is increased in cow's blood during early lactation due to negative energy balance (NEB). After calving, there is a tendency to use body reserves due to increased metabolic demands in high milkyielding cows. Researchers have reported detrimental effects of NEB on metabolic processes, milk yield per lactation, and the immune system, along with other health problems [4-6]. Hyperketonemia (HYK) impairs the health of dairy cows by increasing the risk of onset of other early lactation diseases and negatively affects the reproductive status after calving. Walsh et al. [7] observed significant differences between cows with and without HYK in terms of reproduction performance. Likewise, Rutherford et al. [8] reported that high milk-yielding cows need a positive energy balance for reproductive success. Moreover, there may be an association between reproduction performance and milk yield of cows with HYK. In cows with low milk yield levels, HYK was found to be associated with lower risk of pregnancy to first insemination [9]. Moderate blood BHB levels during the early postpartum period affect response to the hormonal estrus synchronization protocol [10]. Postpartum return to estrus is associated with high concentration of estradiol and low concentration of BHB in early lactation [11]. In addition, other factors, such as the season of calving, breed, and management, should be considered for diagnosis of HYK in dairy cattle [12]. Daily energy balance may be the best indicator of metabolic load in dairy cows, but this is limited in animal breeding practice [13]. It requires the use of different and easy indirect indicators, such as concentration of nonesterified fatty acids (NEFA) and BHB in the blood. For diagnosis of hyperketonemia in dairy cattle, blood BHB concentration is one of the markers as it is a predominant circulating ketone body in ruminants [14]. It has been found that measurement of $\mathrm{BHB}$ is a useful diagnostic tool for prediction of the health of cows [15].

Lithuanian Black and White cows correspond to the model of global high-yielding cow breed. Comprising $70 \%$ of all cattle in Lithuania, they are an old native dairy cattle breed with significant regional and cultural value. Therefore, this study and its results are relevant for not just researchers but also for farmers and breeders of cows with high productivity [16].

The aim of this study was to explore the role of season, parity, and last lactation milk yield of cows on BHB concentration in WK 2 and to evaluate the relationship between BHB concentration and reproductive performance measures such as insemination rate and first insemination day in high-yielding Lithuanian Black and White cows.

\section{Materials and Methods}

This study was carried out in Lithuania on a dairy cattle farm of 1200 dairy cows kept in a loose housing system and located at $(54.436224,23.246784)$ according to the World Geodetic System from October 2018 to September 2019. The experiment was carried out in a geographic place determined as humid continental climate by W. Köppen [17], also known as hemiboreal climate. The average temperature isotherm is $-4.5^{\circ} \mathrm{C}$ in January and $17.5^{\circ} \mathrm{C}$ in July. The average peak temperature for the months of June, July, and August is $20.1^{\circ} \mathrm{C}$. The average temperature for the months of December, January, and February is $-3.6{ }^{\circ} \mathrm{C}$. The detected humidity is lowest in winter months (December, 66-77\%) and highest in summer months (May, 81-91\%).

Seasonal effects were examined by examining the concentration of BHB in WK 2 in spring, summer, autumn, and winter.

In total, 692 Lithuanian Black and White fresh dairy cows were selected for this experiment. The cows had 1-8 lactations and were clinically healthy (without any clinical sign of metritis, lameness, mastitis, displaced abomasum, or indigestion, with an average rectal temperature of $38.8^{\circ} \mathrm{C}$ ). Cows were milked three times per day. The average milk production during last lactation (305 DIM) was $9613 \pm 39.97 \mathrm{~kg}$ per cow. All the milked cows were fed ad libitum with the same total mix ratio twice a day $(06: 00$ and 18:00 h). Rations were calculated on the "HYBRIMIN Futter 2008" system, which is based on the 
German approved DLG standards [18]. The diet was formulated to meet the requirements of a $650 \mathrm{~kg}$ Lithuanian Black and White cow producing $50 \mathrm{~kg} / \mathrm{d}$ (4.2\% fat, 3.5\% proteins). The chemical composition of the ration was as follows: $27.1 \mathrm{~kg}$ DM (of total ration), $174 \mathrm{~g}$ crude protein (per $\mathrm{kg}$ of DM), $258 \mathrm{~g}$ nonfiber carbohydrates (per $\mathrm{kg}$ of DM), $42 \mathrm{~g}$ crude fat (per $\mathrm{kg}$ of $\mathrm{DM}$ ), and $160 \mathrm{~g}$ crude fiber (per $\mathrm{kg}$ of $\mathrm{DM}$ ). The total energy for lactation (NET) was $7.01 \mathrm{MJ} / \mathrm{kg}$ DM and metabolizable energy (ME) was $11.52 \mathrm{MJ} / \mathrm{kg}$ DM. The total mixed ration consisted of $4.7 \mathrm{~kg}$ DM corn silage (17.2\%), $8.13 \mathrm{~kg}$ DM grass silage (29.8\%), $3.2 \mathrm{~kg}$ DM crushed corn grains (11.7\%), $1.37 \mathrm{~kg}$ DM sugar beet pulp silage (5.0\%), $8.5 \mathrm{~kg}$ DM grain concentrate mash (31.1\%), $0.36 \mathrm{~kg}$ DM wheat straw (1.31\%), and $0.77 \mathrm{~kg}$ DM molasses $(2.8 \%)$. The body condition score of the calving cows was in the range of 3.5-3.75 (on a 5-point scale) [19,20].

The blood samples for BHB concentration determination were collected on strips from the ear at 7-10 DIM in the mornings after milking before feeding. The Nova Vet Blood Ketone/Glucose Meter device (Taiwan) and Nova Vet Glucose Test Strips were used to determine blood BHB concentration in WK 2.

Cows were divided into groups according to the season in which they calved:

- Spring-196 cows,

- Summer-79 cows,

- Autumn-188 cows, and

- Winter-229 cows.

Cows were divided into groups according to parity on which the experiment was started: first -195 cows, second -178 , third -148 , fourth -86 cows, fifth -38 cows, sixth25 , seventh-14, and eighth-8.

Reproductive outcomes were collected using the GEA herd management program (Germany). Cows were divided into groups according to insemination rate: $1-333$ cows, 2-171 cows, 3-118 cows, $4-50$ cows, $5-11$ cows, and 6-9 cows.

The statistical analysis of data was performed using the SPSS 25.0 software package (IBM Corp. 2017. IBM SPSS Statistics for Windows, Armonk, NY, USA). Normal distributions were assessed using the Kolmogorov-Smirnov test. The results are presented as the mean \pm standard error of the mean $(\mathrm{M} \pm \mathrm{SE}$ ). Duncan's multiple range test (DMRT) was used to analyze the differences in mean values of normally distributed variables. A probability of less than 0.05 was deemed reliable $(p<0.05)$. The Pearson correlation $(r)$ was determined to define the linear relationship between BHB concentration in WK 2 and season, parity, first insemination time, insemination rate, and milk production. In this study, the regression method was used to measure the effects of independent variables on the dependent variable: insemination rate, first insemination day, and blood BHB concentration in WK 2.

\section{Results}

\subsection{Descriptive Results of the Herd}

The average $\mathrm{BHB}$ concentration in WK 2 of all cows was $0.79 \pm 0.30 \mathrm{nmol} / \mathrm{L}$. The lowest $(0.59 \mathrm{nmol} / \mathrm{L}) \mathrm{BHB}$ concentration was on the 65 th DIM and highest $(1.14 \mathrm{nmol} / \mathrm{L})$ on the 105th DIM. The average milk yield during last lactation ( $305 \mathrm{~d})$ of all cows was in the range of 7008-13,669 kg. The average first insemination day was $81.40 \pm 3.77$ days, and the insemination rate of all cows was $1.98 \pm 1.06$ times.

\subsection{Effect of Season and Parity on BHB Concentration in WK 2}

The effect of the season on blood BHB concentration in WK 2 was statically significant (Figure 1A). The mean BHB concentration in WK 2 was $15.73 \%$ higher in summer compared to spring $(p<0.001)$ and $13.48 \%$ higher in summer compared to winter $(p<0.01)$, representing statistically significant differences. The mean BHB concentration in WK 2 was $6.74 \%$ higher in summer compared to autumn, which was a noticeable difference but not statistically significant $(p>0.05)$. The mean BHB concentration in WK 2 was $9.64 \%$ higher in autumn compared to spring $(p<0.05)$ and $7.23 \%$ higher in autumn compared to winter 
$(p>0.05)$. The difference $(2.67 \%)$ between the mean BHB concentration in WK 2 in spring and winter was not statically significant.

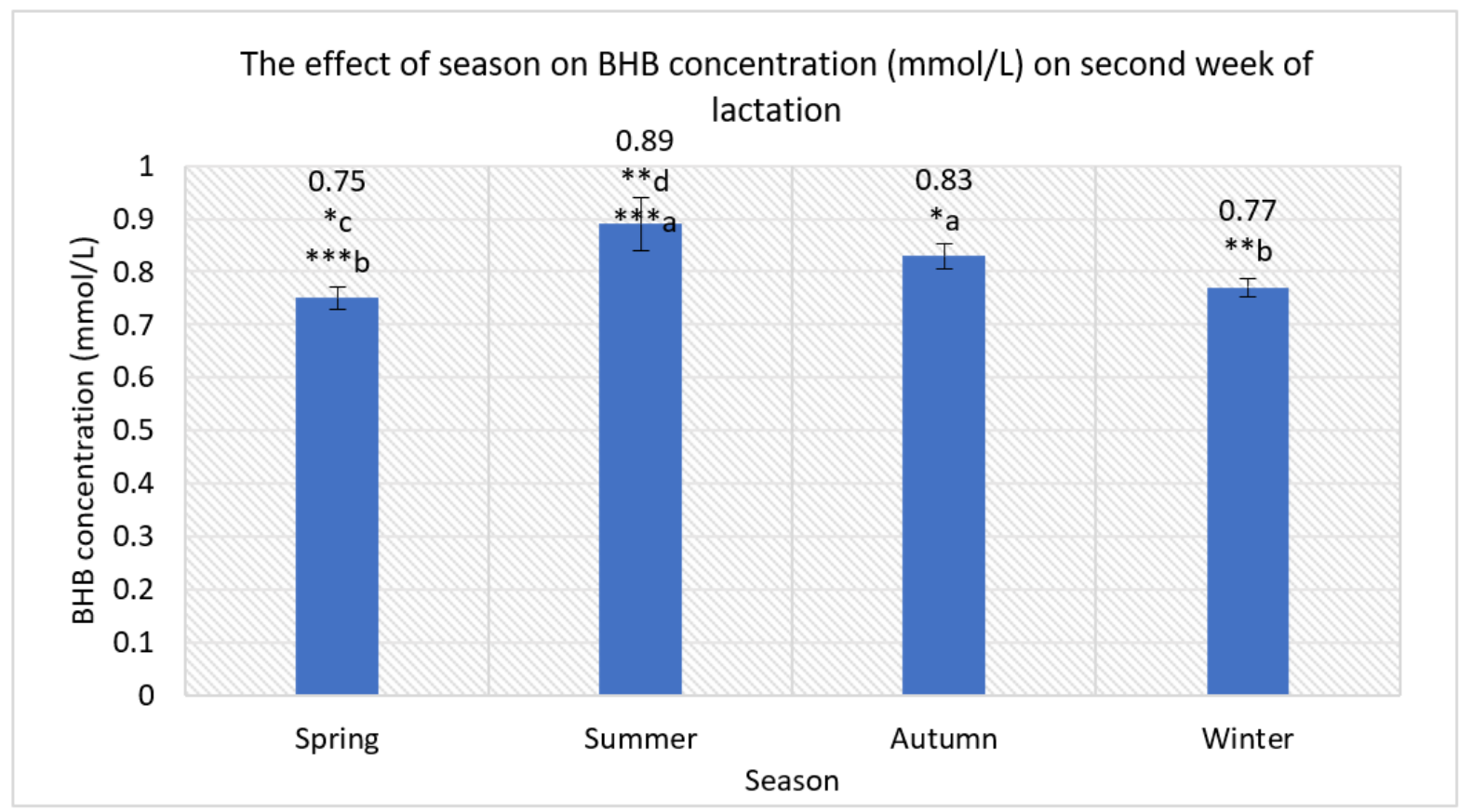

(A)

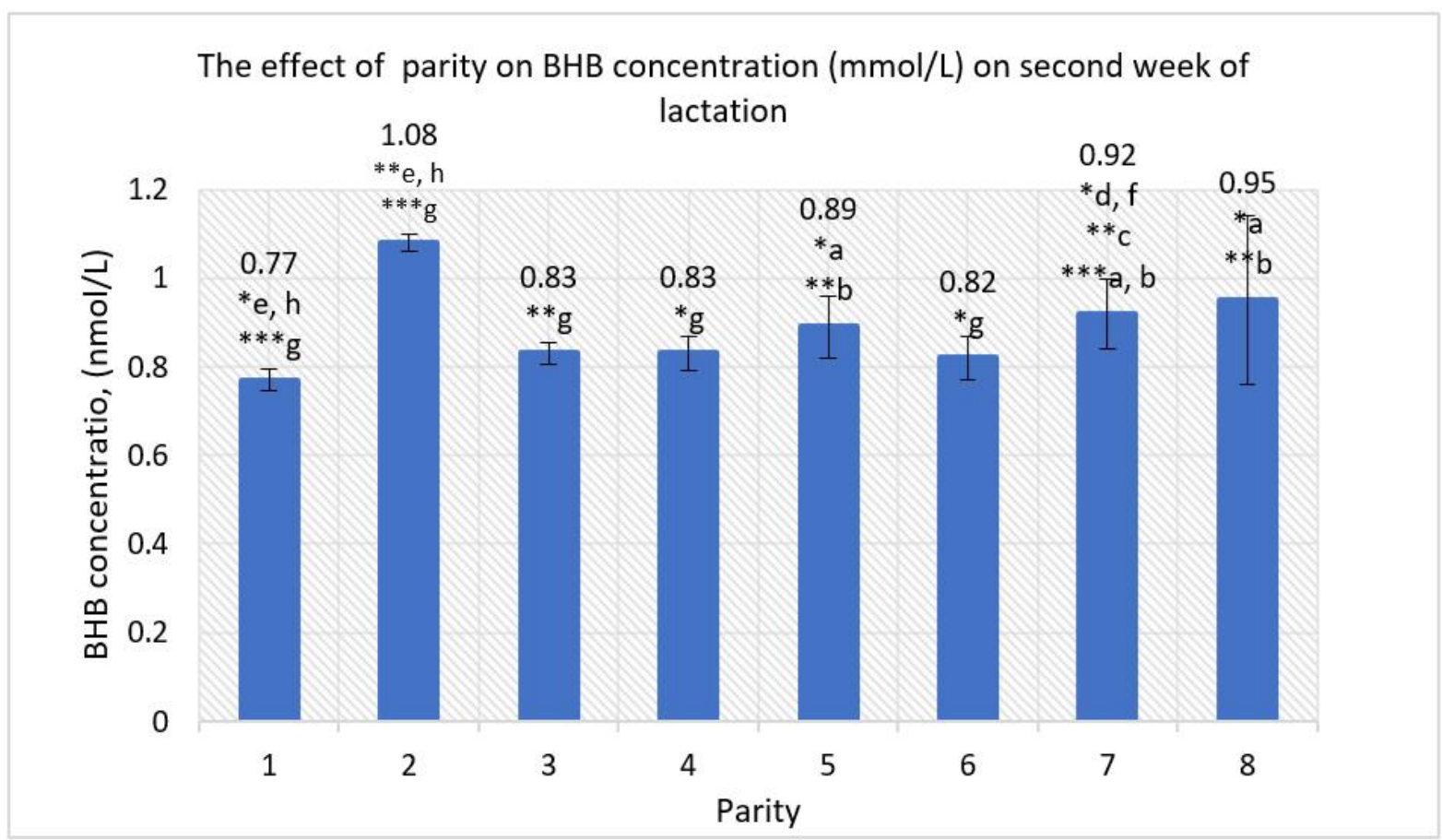

(B)

Figure 1. (A) The effect of season on mean values of BHB concentration on second week of lactation (mmol/L). a, b, c, d-marking with different letters indicates the mean differences between seasons (spring, summer, autumn, and winter). ${ }^{* *} p<0.001{ }^{* *} p<0.01 ;{ }^{*} p<0.05$. (B) The effect of parity on BHB concentration ( $\mathrm{mmol} / \mathrm{L}$ ) on second week of lactation. a, b, c, d, e, f, g, h-marking with different letters indicates mean differences between the investigated indicators. ${ }^{* * *} p<0.001 ;{ }^{* *} p<0.01$; $* p<0.05$. 
We observed significant differences between mean BHB concentration in WK 2 and the parity of cows (Figure 1B). Significant differences were obtained between primiparous and multiparous cows for $\mathrm{BHB}$ concentration in $\mathrm{WK} 2$, indicating that multiparous dairy cows had higher BHB concentration compared to primiparous ones $(14.44 \% ; p<0.05)$. Statistically significant differences were estimated between the mean BHB concentration in different lactations (Table 1).

Table 1. Statistically significant differences between lactations with higher and lower BHB concentration.

\begin{tabular}{ccc}
\hline $\begin{array}{c}\text { Lactations with Higher vs. } \\
\text { Lower BHB Concentration }\end{array}$ & Different in Percents (\%) & $\boldsymbol{p}$ Value $(\boldsymbol{p}<)$ \\
\hline 1 vs. 5 & 13.48 & 0.05 \\
1 vs. 7 & 16.3 & 0.001 \\
1 vs. 8 & 18.95 & 0.05 \\
2 vs. 7 & 14.81 & 0.001 \\
2 vs. 5 & 17.59 & 0.01 \\
2 vs. 8 & 12.04 & 0.01 \\
3 vs. 7 & 9.78 & 0.01 \\
4 vs. 7 & 9.78 & 0.05 \\
6 vs. 7 & 13.68 & 0.05 \\
\hline
\end{tabular}

The other differences between the mean BHB concentration in WK 2 in different lactations were not statistically significant (Figure 1B).

\subsection{The Relationship between Blood BHB Concentration in WK 2 and Milk Yield Per Last Lactation (305d)}

We observed significant differences between milk yield per lactation ( $305 \mathrm{~d}$ ) based on parity $(p<0.001)$. We estimated the lowest milk yield on the eighth lactation, which was $23.06 \%$ lower compared to the highest in the fifth lactation $(p<0.001)$. High statistically significant differences $(p<0.001)$ were observed for the lowest milk yield of cows in the second lactation compared to the third, fourth, fifth, sixth, and seventh lactations (12.95\%, $14.84 \%, 19.55 \%, 14.63 \%$, and $16.64 \%$, respectively). Despite the milk yield varying by parity, we did not find a statistically significant relationship between milk yield and BHB concentration in WK $2(p>0.05)$, as shown in Table 2.

Table 2. The results of milk yield by parity and relationship of the last lactation milk yield with BHB concentration in WK 2.

\begin{tabular}{|c|c|c|c|}
\hline Parity & Milk Yield, kg (305 d) & $\begin{array}{l}\text { Correlation of Milk Yield of } \\
\text { Last Lactation ( } 305 \mathrm{~d}) \text { with BHB } \\
\text { in WK } 2 \text { on Current Lactation }\end{array}$ & $\begin{array}{l}p \text { Value of } \\
\text { Correlation } \\
\text { Coefficient }\end{array}$ \\
\hline 1 & - & - & - \\
\hline 2 & $\begin{array}{c}8717.10 \pm 96.90 \\
* * * \text { c,d,e,f,g }\end{array}$ & -0.004 & 0.963 \\
\hline 3 & $\begin{array}{c}10,013.87 \pm 116.40 * * * \\
b,{ }^{* *} \mathrm{e}, \mathrm{h}\end{array}$ & 0.055 & 0.505 \\
\hline 4 & $\begin{array}{c}10,235.76 \pm 201.01^{* * *} b \\
* * h,{ }^{*} \mathrm{e}\end{array}$ & 0.039 & 0.725 \\
\hline 5 & $\begin{array}{c}10,834.76 \pm 231.24 * * * b, h, \\
* * c_{1}^{*} d\end{array}$ & -0.088 & 0.601 \\
\hline 6 & $\begin{array}{c}10,210.45 \pm 307.53^{* * *} b \\
* * h\end{array}$ & -0.253 & 0.223 \\
\hline 7 & $\begin{array}{c}10,457.25 \pm 430.99 * * * \\
b,{ }^{*} \mathrm{~h}\end{array}$ & -0.195 & 0.505 \\
\hline 8 & $\begin{array}{c}8335.80 \pm 1293.70 * * * \mathrm{e}, \\
* * \mathrm{c}, \mathrm{d}\end{array}$ & 0.320 & 0.536 \\
\hline
\end{tabular}




\subsection{The Effect of BHB Concentration on Reproductive Outcomes}

We estimated negatively statistically significant influence of BHB concentration in WK 2 on insemination rate (Figure 2). Cows with insemination rate 1 had 22.22\% lower BHB concentration in WK 2 than cows with insemination rate $4(p<0.001)$ and $9.41 \%$ lower than cows with insemination rate $3(p<0.05)$. Cows with insemination rate 2 had $24.24 \%$ lower BHB concentration in WK 2 compared to cows with insemination rate $4(p<0.001)$ and $11.76 \%$ lower than cows with insemination rate $3(p<0.05)$. Cows with insemination rate 3 had $14.14 \%$ lower BHB concentration in WK 2 than cows with insemination rate $4(p<0.01)$. We observed that as the blood BHB concentration in WK 2 increased, the insemination rate also had a tendency to increase $\left(y=0.0297 x+0.746, R^{2}=0.4109\right)$.

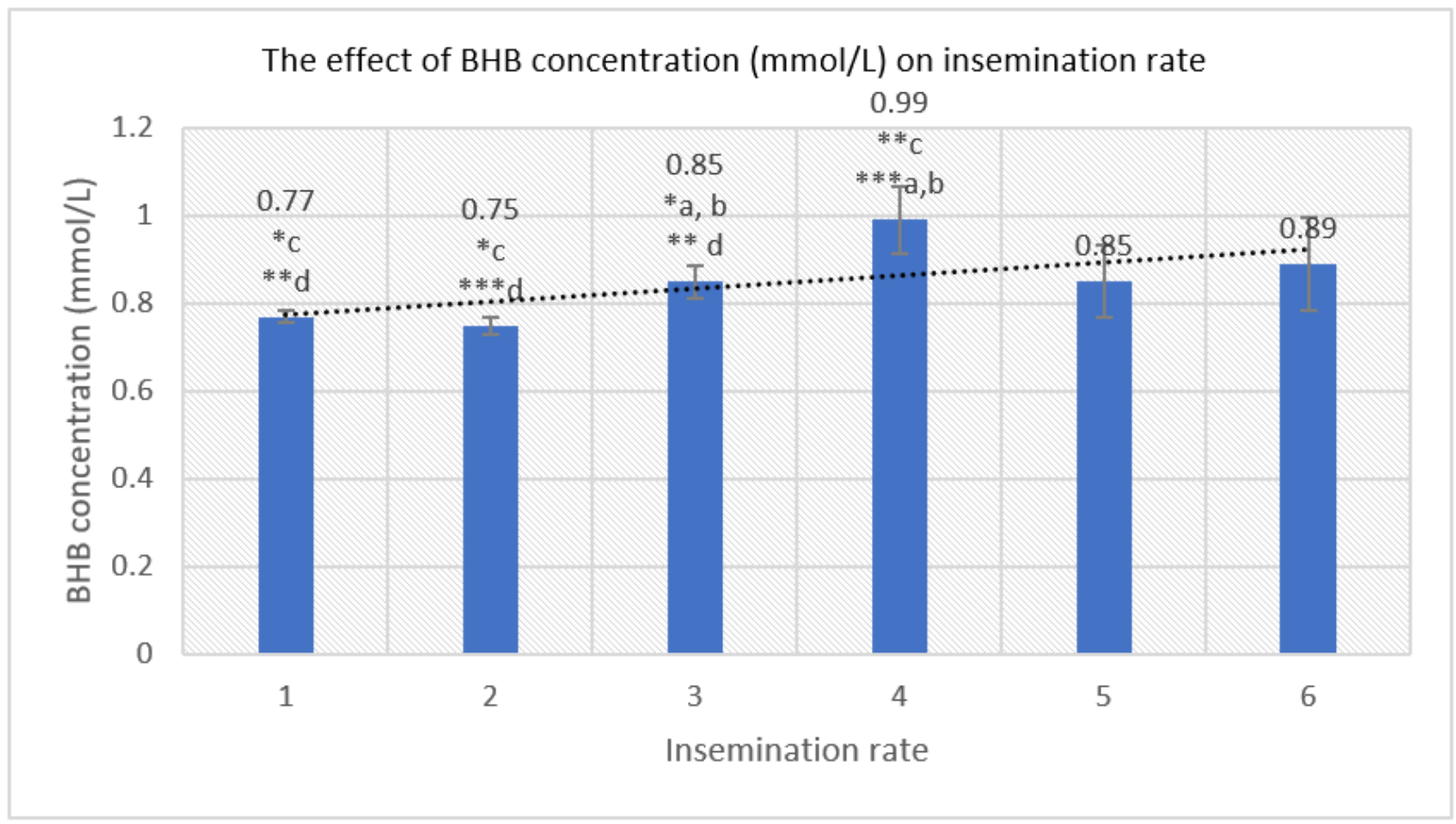

Figure 2. The relationship between mean BHB concentration ( $\mathrm{mmol} / \mathrm{L}$ ) on second week of lactation and insemination rate. $\mathrm{a}-\mathrm{d}-$ marking with different letters indicates the mean differences between the investigated indicators. ${ }^{* *} p<0.001 ;{ }^{* *} p<0.01 ; * p<0.05$.

Higher BHB concentration in WK 2 was related to delayed first insemination day. The correlation coefficient between blood BHB concentration in WK 2 and first insemination day was weak positive but statistically significant $(r=0.194, p<0.001)$, Figure 3.

We estimated a statistically significant relationship between season and insemination rate $(p<0.01)$, as shown in Table 3 . Cows inseminated in autumn had the lowest mean insemination rate $(14.85 \%$ lower compared to cows that were inseminated in spring and $20.37 \%$ lower than those inseminated in summer, $p<0.01$ ). A statistically significant relationship was found between insemination rate and $\mathrm{BHB}$ concentration in WK 2 in spring $(p<0.01)$ and in summer and autumn $(p<0.05)$. Statistically significant mean differences were also detected between first insemination day in different seasons. Analysis showed that the first insemination was $6.93 \%$ earlier in spring compared to autumn and $6.35 \%$ earlier compared to winter $(p<0.001)$. A statistically significant relationship was also found between first insemination day and BHB concentration in spring $(p<0.001)$ and winter $(p<0.01)$. 


\section{BHB concentration $(\mathrm{mmol} / \mathrm{L})$ relation with first insemination day}

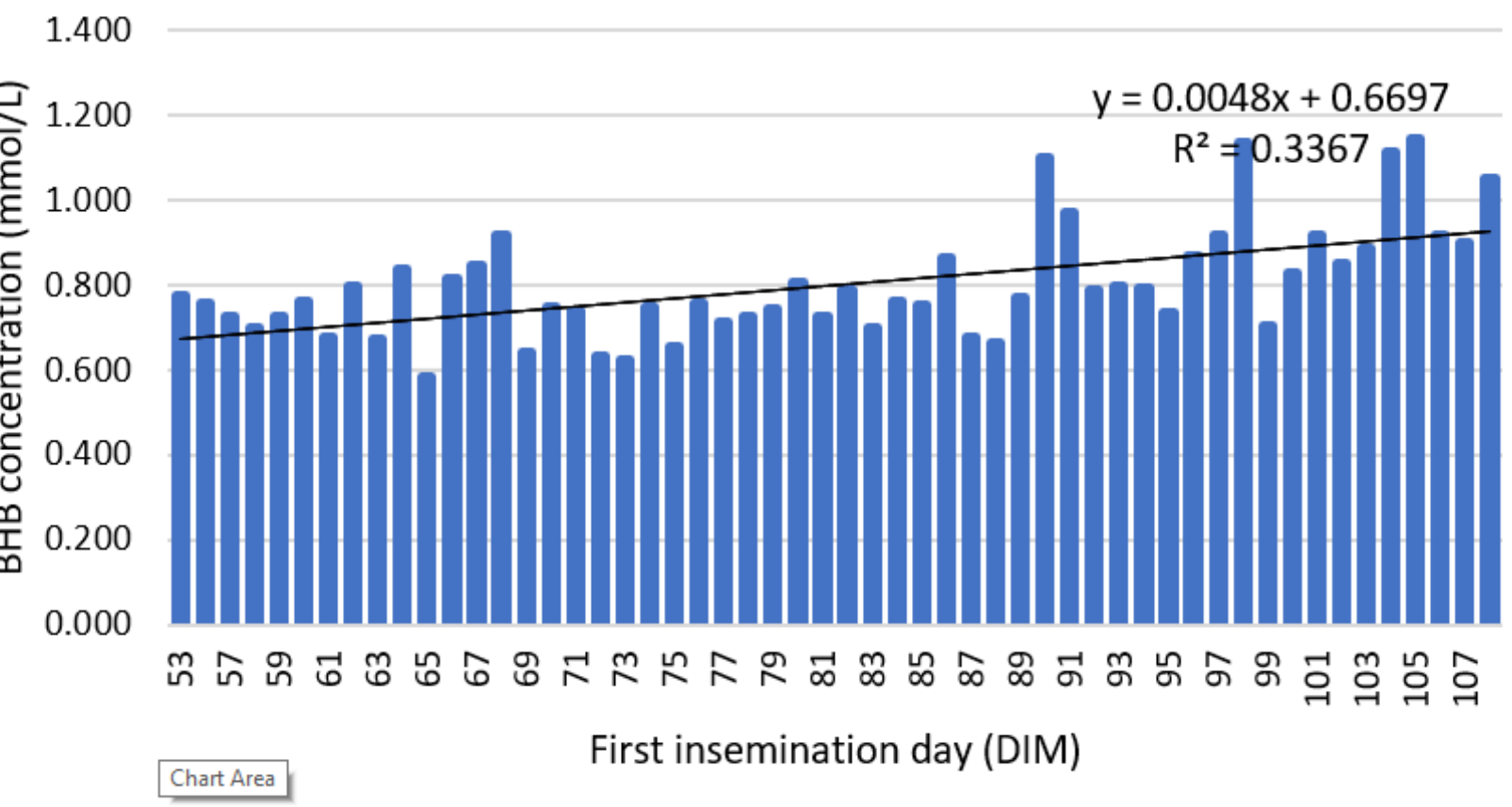

Figure 3. The effect of mean BHB concentration $(\mathrm{mmol} / \mathrm{L})$ on second week of lactation on first insemination day.

Table 3. The results of insemination rate and first insemination day in different seasons and relationship between insemination rate and BHB concentration and first insemination day and BHB concentration.

\begin{tabular}{cccccc}
\hline Season & $\begin{array}{c}\text { Insemination } \\
\text { Rate }\end{array}$ & $\begin{array}{c}\text { Correlation of } \\
\text { Insemination Rate } \\
\text { with BHB in WK } 2\end{array}$ & $\begin{array}{c}\text { First Insemination } \\
\text { Day (DIM) }\end{array}$ & $\begin{array}{c}\text { Correlation of First } \\
\text { Insemination Day } \\
\text { with BHB in WK 2 }\end{array}$ & $\begin{array}{c}p \text { Value of } \\
\text { Correlation } \\
\text { Coefficient }\end{array}$ \\
\hline Spring & $2.02 \pm 0.09^{* *} \mathrm{c}$ & $0.219^{* *}$ & $\begin{array}{c}77.55 \pm 0.89 * * \mathrm{~b}, \\
* * * \\
\mathrm{c}, \mathrm{d}\end{array}$ & 0.296 & 0.001 \\
\hline Summer & $2.16 \pm 0.13^{* *} \mathrm{c}$ & $0.241^{*}$ & $82.49 \pm 1.50^{* *} \mathrm{a}$ & 0.148 & 0.192 \\
\hline Autumn & $1.72 \pm 0.08^{* *} \mathrm{a}, \mathrm{b}$ & $0.163^{*}$ & $83.32 \pm 1.06^{* * *} \mathrm{a}$ & 0.135 & 0.065 \\
\hline Winter & $1.92-0.07$ & 0.076 & $82.81 \pm 0.98^{* * *} \mathrm{a}$ & 0.170 & 0.01 \\
\hline
\end{tabular}

$\mathrm{a}-\mathrm{d}$-marking with different letters indicates the mean differences between seasons (spring, summer, autumn, and winter). ${ }^{* * *} p<0.001 ;{ }^{* *} p<0.01 ;{ }^{*} p<0.05$.

The insemination rate was found to differ between different lactations (Table 4). The highest mean was detected in the sixth lactation $(21.61 \%$ higher compared to the first lactation and $22.03 \%$ compared to the third lactation, $p<0.05)$. A statistically significant relationship was found between insemination rate and BHB concentration in WK 2 in the first lactation $(p<0.01)$ and in the third and fourth lactations $(p<0.05)$. No statistically significant mean differences were estimated between first insemination day in different lactations $(p>0.05)$. A statistically significant relationship was found between first insemination day and BHB concentration in WK 2 in the fourth $(p<0.001)$, third $(p<0.01)$, and first $(p<0.05)$ lactations. 
Table 4. The results of insemination rate, first insemination day in different lactations, and relationship between insemination rate and BHB concentration and insemination day and BHB concentration.

\begin{tabular}{ccccccc}
\hline Parity & $\begin{array}{c}\text { Insemination } \\
\text { Rate }\end{array}$ & $\begin{array}{c}\text { Correlation of } \\
\text { Insemination Rate } \\
\text { with BHB in WK } 2\end{array}$ & $\begin{array}{c}p \text { Value of } \\
\text { Correlation } \\
\text { Coefficient }\end{array}$ & $\begin{array}{c}\text { First } \\
\text { Insemination } \\
\text { Day }\end{array}$ & $\begin{array}{c}\text { Correlation of First } \\
\text { Insemination Day } \\
\text { with BHB in WK } 2\end{array}$ & $\begin{array}{c}p \text { Value of } \\
\text { Correlation } \\
\text { Coefficient }\end{array}$ \\
\hline 1 & $1.85 \pm 0.07^{*} \mathrm{f}$ & 0.219 & 0.01 & $81.18 \pm 1.03$ & 0.154 & 0.032 \\
\hline 2 & $2.03 \pm 0.09$ & 0.033 & 0.663 & $81.28 \pm 1.03$ & 0.127 & 0.097 \\
\hline 3 & $1.84 \pm 0.09 * \mathrm{f}$ & 0.199 & 0.05 & $80.20 \pm 1.18$ & 0.006 \\
\hline 4 & $1.91 \pm 0.13$ & 0.219 & 0.05 & $82.24 \pm 1.55$ & 0.360 & 0.001 \\
\hline 5 & $1.92 \pm 0.16$ & 0.172 & 0.303 & $84.00 \pm 2.57$ & 0.216 & 0.193 \\
\hline 6 & $2.36 \pm 0.26^{*} \mathrm{a}, \mathrm{c}$ & -0.011 & 0.959 & $82.72 \pm 2.89$ & -0.054 & 0.798 \\
\hline 7 & $1.64 \pm 0.23$ & 0.264 & 0.362 & $82.93 \pm 3.72$ & 0.139 & 0.127 \\
\hline 8 & $1.83 \pm 0.31$ & 0.255 & 0.625 & $86.17 \pm 6.26$ & 0.811 \\
\hline
\end{tabular}

\section{Discussion}

In our study, higher statistically significant difference in mean blood BHB concentration on second week of lactation (WK 2) of cows was detected in summer compared to spring and in summer compared to winter. A study in Iran with the Holstein breed of cows showed that the blood BHB concentration in cows can be affected by factors such as season of calving, breed, and herd management [21]. In the present investigation, the results revealed the effect of parity and season on prevalence of HYK. Previous studies with the Holstein breed of cows have detected greater prevalence of HYK in spring, but Vanholder et al. [22] and Santschi et al. [23] reported contrasting results on the effect of season on prevalence of HYK (late autumn and winter or summer). Antanaitis et al. [24] carried out research on Lithuanian Black and White cows and reported that milk BHB concentration had a tendency to increase with increasing number of lactations. Consequently, the highest level of BHB was estimated in the oldest cows, which is similar to our results. However, the authors also reported that BHB concentration in multiparous cows was higher than in primiparous cows, which is opposite to the findings of this study.

A study with Brown Swiss cows reported that multiparous cows use dietary energy more effectively compared to primiparous cows [25]. In the research by Piñeyrúa et al. [26] with Holstein cows, the high increase in BHB concentration of first lactation cows resulted from adaptation to a new technological process, and cows that could not adapt to the new status were removed from the herd. Multiparous cows have more adequate and suitable metabolism for the lactation process and have lower blood BHB concentration compared to primiparous cows. According to Roberts et al. [27] and McArt et al. [28], cows with high blood BHB concentration should be removed and culled from the herd in early lactation. Mohammed et al. [29] reported differences in relation to the number of lactations. Their results clearly revealed that prevalence of HYK in cows depends on the age of the cow or the calving month.

In the present study, we did not find a relationship between BHB concentration in WK 2 and milk yield ( $305 \mathrm{~d}$ ). Moreover, no statistically significant differences were observed between milk yield ( $305 \mathrm{~d}$ ) of primiparous and multiparous dairy cows and blood BHB concentration. Several studies have reported contradictory results, with researchers finding a relationship between production and blood or milk BHB concentration $[19,28,30]$. However, no significant differences were observed between cows with and without HYK by van der Drift et al. [31], Djoković et al. [32], and Chandler et al. [15]. The negative impact of HYK in cows of the Holstein breed was more pronounced in the first week compared to the second week of lactation [5,21]. Kayano and Kataoka [33] and Santschi et al. [23] reported that differences in milk yield between cows with and without HYK increased during lactation due to the cumulative NEB in hyperketonemic cows. 
In this study, an increase in BHB concentration in WK 2 negatively affected the fertility traits of cows, including the insemination rate and first insemination day (DIM). We found a relationship between reproduction outcome and BHB concentration in WK 2 depending on the season $(p<0.01)$. The highest statistically significant correlation was detected between $\mathrm{BHB}$ concentration and reproduction outcomes in spring. We did not find an obvious relationship between BHB concentration in WK 2 and reproduction outcomes, but there was a statistically significant, weak correlation in the fourth, third, and first lactations. Therefore, BHB concentration in WK 2 should be analyzed in different seasons and lactations in order to increase reproduction outcomes. In a study with Ayrshire cows, Grohn et al. [34] also reported that prevalence of HYK increased with age, with the peak being observed in the third and fifth lactations.

Rutherford et al. [8] reported that animals with HYK had greater insemination rate, lower peak activity, shorter activity at estrus, and longer interval from calving to first observed estrus compared to animals without HYK. Walsh et al. [7] carried out research with Holstein cows and observed the significant differences in reproduction success between cows with and without HYK. The authors found that increased BHB levels in the first two weeks after calving negatively affected pregnancy status at first artificial insemination. These results can be considered to be in line with our results. On the other hand, studies by Chapinal et al. [35] and McArt et al. [28] with Holstein breed of cows did not show significant differences between animals with and without HYK in terms of reproduction successes.

The discussion shows that similar studies have been performed with other breeds of dairy cattle, but research findings in the context of Lithuanian Black and White breed of dairy cows is lacking.

\section{Conclusions}

According to the results of our study, we can conclude that BHB concentration of Lithuanian Black and White cows in WK 2 depends on the season and parity of cows. However, BHB concentration in WK 2 is not related to milk yield (305 d) in Lithuanian Black and White cows. Increased BHB concentration clearly impacts the fertility rates, with insemination rate and first insemination day having a statistically significant relationship with BHB concentration in WK 2 in different seasons and lactations of cows. Analysis of $\mathrm{BHB}$ concentration in WK 2 can be a predictor of reproductive performance traits.

Author Contributions: I.M.-writing—review and editing, software, formal analysis., G.P.—supervision, methodology, writing-review and editing, L.A.—software, formal analysis, and review and editing. R.A.-review and editing, A.Y.—software, formal analysis, and review and editing, I.T.- review and editing, V.Ž.-methodology, investigation, and writing—review and editing. All authors have read and agreed to the published version of the manuscript.

Funding: No external funding was received for this research.

Institutional Review Board Statement: All the research was conducted in compliance with the Law of Veterinary Medicine of the Republic of Lithuania (new wording from 1 July 2011: No. XI-1189, 30 November 2010: No. 148-7563 (20.10.2012)) and the Law on Animal Welfare and Protection of the Republic of Lithuania (No. XI-2271, 03.10.2012, Official Gazette 2012). Care and usage requirements of animals used for scientific and educational purposes were approved by the State Food and Veterinary Service by official letter (No. B1-866, 31.10.2012).

Informed Consent Statement: Not applicable.

Data Availability Statement: The research was conducted on a private farm (located by World Geodetic System $(54.436224 ; 23.246784)$ ) based on private data from that farm.

Conflicts of Interest: The authors declare no conflict of interest. The funders had no role in the design of the study; in the collection, analyses, or interpretation of data; in the writing of the manuscript; or in the decision to publish the results. 


\section{References}

1. Castillo, C.; Hernandez, J.; Bravo, A.; Lopez-Alonso, M.; Pereira, V.; Benedito, J.L. Oxidative status during late pregnancy and early lactation in dairy cows. Vet. J. 2005, 169, 286-292. [CrossRef] [PubMed]

2. Le-Blanc, S. Health in the transition period and reproductive performance. Adv. Dairy Technol. 2010, 22, 97-110.

3. Mahrt, A.; Burfeind, O.; Heuwieser, W. Evaluation of hyperketonemia risk period and screening protocols for early-lactation dairy cows. J. Dairy Sci. 2015, 98, 3110-3119. [CrossRef] [PubMed]

4. Hammon, D.S.; Evjen, I.M.; Dhiman, T.R.; Goff, J.P.; Walters, J.L. Neutrophil function and energy status in Holstein cows with uterine health disorders. Vet. Immunol. Immunopathol. 2006, 113, 21-29. [CrossRef]

5. Duffield, T.F.; Lissemore, K.D.; McBride, B.W.; Leslie, K.E. Impact of hyperketonemia in early lactation dairy cows on health and production. J. Dairy Sci. 2009, 92, 571-580. [CrossRef]

6. Gábor, G.; Balogh, O.G.; Kern, L.; Gábor, P.R.; Fébel, H. Nutrition, Metabolic Status and Reproductive Efficiency in Dairy Herds. Open J. Anim. Sci. 2016, 5, 75-84. [CrossRef]

7. Walsh, R.B.; Walton, J.S.; Kelton, D.F.; LeBlanc, S.J.; Leslie, K.E.; Duffield, T.F. The effect of subclinical ketosis in early lactation on reproductive performance of postpartum dairy cows. J. Dairy Sci. 2007, 90, 2788-2796. [CrossRef]

8. Rutherford, A.J.; Oikonomou, G.; Smith, R.F. The effect of subclinical ketosis on activity at estrus and reproductive performance in dairy cattle. J. Dairy Sci. 2016, 99, 4808-4815. [CrossRef]

9. Rodriguez, Z.; Wynands, E.; Shepley, E.; Baumgard, L.H.; Cramer, G.; Caixeta, L.S. Exploring the role of milk yield in the first week of lactation on the association between hyperketonemia and reproductive performance in dairy cattle. JDS Commun. 2022, 3, 7-12. [CrossRef]

10. Najm, N.A.; Zimmermann, L.; Dietrich, O.; Rieger, A.; Martin, R.; Zerb, H. Associations between motion activity, ketosis risk and estrus behavior in dairy cattle. Prev. Vet. Med. 2020, 175, 104857. [CrossRef]

11. Salar, S.; Bastan, A. Effects of blood $\beta$-hydroxybutyric acid levels on the response to Ovsynch in primiparous cows. Anim. Reprod. 2017, 14, 1087-1094. [CrossRef]

12. Benedet, A.; Manuelian, C.L.; Zidi, A.; Penasa, M.; De Marchi, M. Invited review: $\beta$-hydroxybutyrate concentration in blood and milk and its associations with cow performance. Animal 2019, 13, 1676-1689. [CrossRef] [PubMed]

13. Coffey, M.P.; Simm, G.; Oldham, D.J.; Hill, W.G.; Brotherstone, S. Genotype and Diet Effects on Energy Balance in the First Three Lactations of Dairy Cows. J. Dairy Sci. 2004, 87, 4318-4326. [CrossRef]

14. Pascottini, O.B.; LeBlanc, S.J. Metabolic markers for purulent vaginal discharge and subclinical endometritis in dairy cows. Theriogenology 2020, 155, 43-48. [CrossRef] [PubMed]

15. Chandler, T.L.; Pralle, R.S.; Dórea, J.R.R.; Poock, S.E.; Oetzel, G.R.; Fourdraine, R.H.; White, H.M. Predicting hyperketonemia by logistic and linear regression using test-day milk and performance variables in early-lactation Holstein and Jersey cows. J. Dairy Sci. 2018, 101, 2476-2491. [CrossRef]

16. Lapickas, R.; Griciuvienè, L.; Paulauskas, A.; Urbonavičius, V. The genetic variability of the Holstein blood parts having Lithuanian Black-and-White cattle breed. In Proceedings of the ICSB 3rd International Conference, Kaunas, Lithuania, 2-4 May 2019; p. 246. Available online: https://hdl.handle.net/20.500.12259/99597 (accessed on 21 December 2021).

17. Köppen, W. Versuch einer Klassifikation der Klimate, vorzugsweise nach ihren Beziehungen zur Pflanzenwelt. Geogr. Z. 1900, 6, 593-611, 657-679. Available online: http:/ / www.jstor.org/stable/27803924 (accessed on 21 December 2021).

18. Gruber, L.; Pries, M.; Schwarz, F.J.; Spiekers, H.; Staudacher, W. Schätzung der Futteraufnahme bei der Milchkuh. DLG-Information 2006, 1, 1-29.

19. Edmondson, A.J.; Lean, L.J.; Weaver, L.D.; Farver, T.; Webster, G.A. Body condition scoring chart for Holstein dairy cows. J. Dairy Sci. 1989, 73, 68-78. [CrossRef]

20. Ferguson, J.D.; David, T.; Galligan, T.; Thomsen, N. Principal descriptors of body condition score in Holstein cows. J. Dairy Sci. 1994, 77, 2695-2703. [CrossRef]

21. Ruoff, J. On-Farm Diagnosis and Effects of Subclinical Ketosis on Milk Production and Reproductive Performance in Dairy Cows. Ph.D. Thesis, Freie Universität Berlin, Berlin, Germany, 2018. [CrossRef]

22. Vanholder, T.; Papen, J.; Bermers, R.; Vertenten, G.; Berge, A.C.B. Risk factors for subclinical and clinical ketosis and association with production parameters in dairy cows in the Netherlands. J. Dairy Sci. 2015, 98, 880-888. [CrossRef] [PubMed]

23. Santschi, D.E.; Lacroix, R.; Durocher, J.; Duplessis, M.; Moore, R.K.; Lefebvre, D.M. Prevalence of elevated milk $\beta$-hydroxybutyrate concentrations in Holstein cows measured by Fourier-transform infrared analysis in Dairy Herd Improvement milk samples and association with milk yield and components. J. Dairy Sci. 2016, 99, 9263-9270. [CrossRef] [PubMed]

24. Antanaitis, R.; Juozaitienè, V.; Televičius, M.; Malašauskienè, D. Changes in the real-time registration of milk $\beta$-hydroxybutyrate according to stage and lactation number, milk yield, and status of reproduction in dairy cows. Pol. J. Vet. Sci. 2018, 21, 763-768. [CrossRef] [PubMed]

25. Grandl, F.; Zeitz, J.O.; Clauss, M.; Furger, M.; Kreuzer, M.; Schwarm, A. Evidence for increasing digestive and metabolic efficiency of energy utilization with age of dairy cattle as determined in two feeding regimes. Animal 2018, 12, 515-527. [CrossRef] [PubMed]

26. Piñeyrúa, J.T.M.; Fariña, S.R.; Mendoza, A. Effects of parity on productive, reproductive, metabolic and hormonal responses of Holstein cows. Anim. Reprod. Sci. 2018, 191, 9-21. [CrossRef]

27. Roberts, T.; Chapinal, N.; LeBlanc, S.J.; Kelton, D.F.; Dubuc, J.; Duffield, T.F. Metabolic parameters in transition cows as indicators for early-lactation culling risk. J. Dairy Sci. 2012, 95, 3057-3063. [CrossRef] [PubMed] 
28. McArt, J.A.A.; Nydam, D.V.; Oetzel, G.R. Epidemiology of subclinical ketosis in early lactation dairy cattle. J. Dairy Sci. 2012, 95, 5056-5066. [CrossRef]

29. Mohammed, N.; Jaiswal, M.; Bihani, D.K. Prevalence of subclinical and clinical ketosis in cattle in and around Bikaner. Biol. Rhythm Res. 2019, 1-9. [CrossRef]

30. Rathbun, F.M.; Pralle, R.S.; Bertics, S.J.; Armentano, L.E.; Cho, K.; Do, C.; Weigel, K.A.; White, H.M. Relationships between body condition score change, prior mid-lactation phenotypic residual feed intake, and hyperketonemia onset in transition dairy cows. J. Dairy Sci. 2017, 100, 3685-3696. [CrossRef]

31. van der Drift, S.G.A.; van Hulzen, K.J.E.; Teweldemedhn, T.G.; Jorritsma, R.; Nielen, M.; Heuven, H.C.M. Genetic and nongenetic variation in plasma and milk $\beta$-hydroxybutyrate and milk acetone concentrations of early-lactation dairy cows. J. Dairy Sci. 2012, 95, 6781-6787. [CrossRef]

32. Djoković, R.; Kurćubić, V.; Ilić, Z.; Cincović, M.; Lalović, M.; Jašović, B.; Bojkovski, J. Correlation between Blood Biochemical Metabolites Milk Yield, Dry Matter Intake and Energy Balance in Dairy Cows during Early and Mid Lactation. Adv. Diabetes Metab. 2017, 5, 26-30. [CrossRef]

33. Kayano, M.; Kataoka, T. Screening for ketosis using multiple logistic regression based on milk yield and composition. J. Vet. Med. 2015, 77, 1473-1478. [CrossRef] [PubMed]

34. Grohn, Y.T.; Erb, H.N.; McCulloch, C.E. Epidemiology of metabolic disorders in dairy cattle: Association among host characteristics, disease and production. J. Dairy Sci. 1989, 72, 1876-1885. [CrossRef]

35. Chapinal, N.; Leblanc, S.J.; Carson, M.E.; Leslie, K.E.; Godden, S.; Capel, M.; Santos, J.E.P.; Overton, M.W.; Duffield, T.F. Herdlevel association of serum metabolites in the transition period with disease, milk production, and early lactation reproductive performance. J. Dairy Sci. 2012, 95, 5676-5682. [CrossRef] 